\title{
WHAT MOTIVATES STUDENTS TO STUDY IN UPPER SECONDARY SCHOOL? A STUDY ON STUDENTS' PERSPECTIVE ON STUDY MOTIVATION IN FOUR DIFFERENT STUDY PROGRAMS IN SWEDEN
}

\author{
LENA BOSTRÖM, GÖRAN BOSTEDT
}

\begin{abstract}
:
Every fourth student in Sweden cancels their upper secondary school education, although the intention behind the new school reform 2011 (GY-11) was to increase the throughput. One important reason for this is a lack of study motivation, which, in turn, has different causes. The authors of this study have chosen to focus on students' perceptions of what is happening in the classroom (i.e., learning and teaching in four different study programs). The purpose of the article is to describe and analyze students' perceptions of what motivates or demotivates them. The research questions are: a) what is important to study motivation?, and b) are there any differences regarding study motivation between programs? The study is based on a web survey of 126 students and four group interviews of 12 students. The interviews were analyzed using thematic content analysis. This is a cross-sectional study that also was analyzed using descriptive statistics and chi-squared tests with correction. The results show the importance of learning and teaching strategies, teachers, and learning enviroments. Some similarities were found between the four upper secondary programs, such as a preference for more practically-oriented pedagogy, short-term goals and quick feedback, varied teaching methods, and good textbooks. However, there are also statistically significant differences between the programs regarding the need for structure, learning methods, and preferred perceptual preferences. The results have implications for teacher education, practicing teachers, and the students themselves. Conducting studies at the group- and program-level to better understand students is a way to develop the didactics for specific study programs and find ways to strengthen students' study motivation.
\end{abstract}

\section{Keywords:}

students' perspectives, study motivation, Sweden, upper secondary school

JEL Classification: 129, D83, 129

\section{Authors:}

LENA BOSTRÖM, Department of Education, Mid Sweden University, Sweden, Email: lena.bostrom@miun.se GÖRAN BOSTEDT, Department of Education, Mid Sweden University, Sweden, Email: goran.bostedt@miun.se 


\section{Citation:}

LENA BOSTRÖM, GÖRAN BOSTEDT (2020). What motivates students to study in upper secondary school? A study on students' perspective on study motivation in four different study programs in Sweden. International Journal of Teaching and Education, Vol. VIII(2), pp. 18-34.,

10.20472/TE.2020.8.2.002 


\section{Introduction}

In Sweden, a new school reform (GY 11) was implemented, with the intention of increasing student throughput. After almost ten years, the results are worse than expected. The actual situation is that every fourth upper secondary school student interrupts their studies. Compared to students who received a final grade in the old system, the throughput is between 2 and 5 percentage points lower than before the reform, depending on the chosen year. Of 355,000 students in upper secondary school, 208,000 can be found in study programs, 102,000 in vocational programs, and 44,900 in introductory programs ${ }^{1}$ (Skolverket, 2020a). $76.6 \%$ of students obtain their degree within three years after ending the program, but in vocational programs, the number is lower, being $71.6 \%$. In real numbers, this means that slightly over 23,000 students leave upper secondary schools in Sweden every year with incomplete grades (Skolverket, 2020a). Among students with parents who have only a presecondary education, the percentage is 35\% (Skolverket, 2018).

There is a situation in Sweden in which some students get through upper secondary school easily, others must fight throughout their school years to get their diploma. A large group of students fails to obtain final grades or drops out of school, and another group has difficulty gaining access to the national programs (introductory program). Incomplete grades or dropping out of school is a problem for individuals as well as for society. Students without complete upper secondary school grades risk ultimately confronting social exclusion and unemployment, and the societal costs for their education double when such people complete their grades through different adult education programs. Voices from both student organizations (Sveriges Elevkårer, 2018) as well as politicians and other stakeholders can be heard, demanding that changes be made in the school system and in Swedish school policy. Many voices offer far-reaching conclusions, including that Swedish school policy has failed. However, different stakeholders have rarely made concrete proposals based on contemporary educational research on the reasons for dropouts or lack of study motivation and the changes that must be made to accomplish this and how to make them.

An important reason for incomplete grades and a high number of school dropouts is a lack of study motivation. More than $50 \%$ of upper secondary school students indicate that they experience low or nonexistent study motivation (Sveriges Elevkårer \& Lärarnas Riksförbund, 2015). The most important factors for increasing student motivation are described as being related to teachers' subject competence, teacher -student relationships, educational support, and access to student health. The interesting question is theno how it is possible to increase study motivation and to understand and minimize the reasons for demotivation. Is the lack of study motivation due to teaching difficulties, the school system, or something else? Other reasons mentioned include the new school system's imposition of higher requirements for admission to the upper secondary school's national program, that Swedish primary school students have declining knowledge results, and that primary school students are less prepared for the increasing demands in upper secondary school (Skolverket, 2016). In our view, there is too little attention given to the relationship between study motivation and such didactical issues as students' personal opinions, teachers' professional skills, and subject didactics. That

\footnotetext{
1 The introductory programs are intended primarily for students who do not have access to a national upper secondary school programs.
} 
students are motivated is a prerequisite for successful learning in schools and is, therefore, important to study. If a large group of students in Sweden today has low or nonexistent study motivation, or if students lack necessary study strategies, how can schools fulfill needed tasks to help students achieve their knowledge goals? How do students think about student motivation and how may they be helped in their search for knowledge? The National Board of Education states:
Lack of motivation makes it difficult to take advantage of school education; conversely, those who do not qualify for teaching can suffer a lack of motivation. Assuming a lack of motivation - and thus corresponding compensation needs - motivation becomes something that needs to be added to the learning processes [our translation]. (Skolverket, 2019, p. 154)

This study focused on four types of upper secondary school programs to analyze study motivation in general, as well as similarities and differences among the programs. The study has chosen to focus on the student's perspective on the issue of study motivation and is based on an extensive web-based questionnaire and group interviews with students. One important reason for this study, apart from the problem areas mentioned earlier, is that research in Sweden on the interaction between individuals and the learning environment in Swedish schools is limited (Blomgren, 2016), and national studies are few (Lundahl et al. 2015). Another important incentive for the study is that there are few Swedish contemporary studies that build on students as informants about their own study motivation (Giota, 2013).

In view of the above problem area, the aim of this article is to describe and analyze the views of students from four upper secondary study programs, regarding what increases or decreases their study motivation. The research questions are:

- What determines the motivation or lack of motivation to study among upper secondary school students in four types of study programs?

- Are there differences among the students in the four programs concerning study motivation?

The results of the study can offer students and teachers insights into better ways to harness the school situation for increased study success. For teachers, this concerns didactical choices, and for students, this relates to individual study strategies. The results can also offer other actors in the school (i.e., head teachers, school administrators, and politicians) indications of a need for, for example, policy statements, regulation documents and/or different types of programs with resource allocations. In this article, we first give a brief introduction of upper secondary schools in Sweden and the new reform for upper secondary schools (GY-11). We then present some relevant previous research in the area, followed by an account of our methodological choices. The final part of the article consists of the results, along with a subsequent discussion and didactical implications.

\subsection{Upper secondary school in Sweden}

Within upper secondary school, there are 18 national programs: 6 university preparatory programs and 12 vocational programs. There are also four introductory programs. A vocational program is a program that leads to a profession, should be the basis for professional activity, and continued vocational training. A university preparation program prepares students for university studies and includes more studies in English and Swedish languages than vocational 
programs. Introductory programs aim to allow unauthorized students to enter a national program or lead to them obtaining a job. All students in such programs follow an individual study plan. There is no degree objective or program structure applied to the study plan that indicates what the education should contain.

The upper secondary school reform in 2011 (GY-11) introduced a new upper secondary school for Sweden. The purpose of the reform was, among other things, "to prepare students for working life and higher studies to a greater extent than before, to clarify the content of the various programs and to increase the throughput" (Skolverket, 2016, p. 12). The reform thus had a clearly defined problem as a background to the changes that the reform implemented. The new reform aimed to improve the study results through higher requirements for admission to the programs and during the implementation of the programs. However, the National Agency for Education's national statistical database on grades in the upper secondary school system (Skolverket, 2020b) notes that the grade point score for students who finished upper secondary school in spring 2019 is at approximately the same average as it was for the students in the old system.

In 2014, four years after the introduction of the new upper secondary school with Gy 11 , the Swedish Student Union and the Teachers' Union conducted a study on throughput in the Swedish secondary school system (Sveriges Elevkårer et al., 2014). The study indicated that the main explanation for the perceived low throughput was a lack of student motivation on the part of the students. According to the study, $53 \%$ of high school students indicated that they felt low student motivation. The proportion is slightly higher among students from vocational programs than among students from university preparatory programs. The most important instruments to raise student motivation are according to the study are: a) the different modes of interaction between the teacher and student and b) access to student health. The new high school reform has not resulted in improved study results. In addition to improving study results, the upper secondary school reform intended to increase throughput in upper secondary school. The results have for this part been disappointing. Available data on the effects of the new upper secondary school system thus show that the results have not yet, to the desired extent, handled all the ambitions that existed with the reform. In the study presented here, we focus particularly on one of the causes that has been mentioned as an important explanation for the success or failure of the students' learning ambitions: study motivation.

\section{Previous research}

There are different definitions and understandings of the concept of study motivation. According to the Swedish Student Union and the Swedish Teachers' Federation's study (2014), the teacher-student interaction and access to student health are the most important factors in raising student motivation. Internal and external motivational factors are important for study results. Study motivation is often described as having internal and external motivation (Ryan \& Deci, 2002). Internally controlled motivation arises when the activity feels engaging and rewarding in itself. Internal motivational factors are about seeking and managing challenges related to an endeavor to satisfy personal interests and use one's abilities (Woolfolk \& Karlberg, 2015). In school, internally motivated students show greater endurance during tasks, seek more understanding in terms of knowledge, and try different strategies to achieve their goals (Giotta, 2017). 
External motivational factors are based more on control, meaning the result or whether there is a reward (e.g., credits, praise, useful skills in working life) or a punishment (e.g., missing student support, delayed studies) that can be predicted determines the motivation of the student.

External motivational factors imply an endeavor aimed at meeting expectations or demands that come from, or are perceived as coming from, outside the individual (Giota, 2017; Woolfolk \& Karlberg, 2015). Externally motivated students adopt more surface learning strategies, often giving up when rewards or benefits are removed (Giota, 2017). The student's motives for their actions and whether their actions are internally or externally motivated are an important factor for study motivation (Jerkeby, 2019). Nonexistent motivation (i.e., study motivation is completely lacking) is a third aspect of motivation (Woolfolk \& Karlberg, 2015). Students give up, blame factors outside of themselves, and do not see the relationship between performance and results (Sjöberg, 1997).

Strategies to increase student motivation can be understood and analyzed from different starting points. Jerkeby (2019) described the complexity in the following words:

It is about teachers who motivate to, and students who are motivated, that is, two aspects that are interrelated. You can be motivated with regard to the content of the learning and / or with regard to the forms of the learning, that is to say with regard to what and with regard to how to learn (our translation). (p. 33)

Motivation strategies, thus, interact with each other in many ways. To contribute to students' study motivation, teachers require a "toolbox" of motivation strategies (Augustsson \& Boström, 2016). Various researchers in the field have mentioned the following strategies: understanding and taking into account the complexity of events, students, and groups in the teaching setting (Giota, 2013); designing the tasks to enable adaptation to both individuals and groups (Boström, 2011a); using constructive evaluations, taking time aspects and didactic diversity into account (Woolfolk \& Karlberg, 2015); using various teaching strategies and active work with metacognitive strategies (Boström, 2011b, 2013); and taking conscious leadership in the classroom (Augustsson \& Boström, 2016; Hattie, 2009). In this context, it is also relevant to pay attention to the emotions that are aroused by success and failure and the teachers' competence to handle this at the group and individual levels (Giota 2013: Lundahl et al., 2013). Teacher strategies that impair student motivation include: ineffective feedback or no feedback (Giota, 2013), lack of connection, overly difficult tasks (Hugo, 2006), slow pace, focus on getting ready and not on learning, poor planning, and punishing leadership. Other demotivating factors are unattractive classrooms and a negative mood in the class (Woolfolk, \& Karlberg, 2015).

Even factors that motivate students are complex. Farrington et al. (2012) point to five crucial factors: study-oriented behavior, endurance in studies, academic "mindset," learning strategies, and social ability. A students' own view of their self-esteem, previous experiences, and individual goals (Hugo, 2006; Wery \& Thomson, 2013) are crucial for study motivation. Moreover, a student being given the opportunity to learn in way that is individually best for them has been noted as being of decisive importance for results (Dunn \& Giggs, 2007). Further, previous research points to the importance of students' perceptions of the tasks (i.e., relevance, utility, difficulty, way of working (Granström, 2012), feedback, grouping, and group dynamics (Håkansson \& Sundberg, 2012; Vinterek, 2006; Woolfolk \& Karlberg, 2015; Zimmerman, 2018). Students' experiences of teachers' overall didactic competence (Hattie, 2009), as well as the importance of relationships (Aspelin, 2018), are also considered to have a serious effect on 
study motivation. As the school places demands on student performance, it should also provide support in an environment to facilitate the occurrence of change where it is difficult to meet requirements and expectations (i.e., in this case, at school) (Karlberg, 2011).

\section{Method}

To fulfill the purpose of the study and answer the research questions, the design of the study used a mixed method approach, followed by an inductive content analysis (Braun \& Clarke, 2006) based on group interviews and a statistical analysis based on selected clusters from the web survey to get a more nuanced picture. Below, we describe the participants, the data collection and analysis, the interviews, the thematic analysis, the web survey, and the statistical analysis.

\subsection{Participants}

The selection principles include students from theoretical and practical programs but also students who do not have access to upper secondary education. All participating persons were informed of the project's aims and current ethical principles of research (Vetenskapsrådet, 2017). We collected data in the fall of 2017. The study included students from four upper secondary school programs: The Social Sciences Program (SSP), the Health and Social care Program (HSP), the Vehicle and Transport Program (VHP), and the Introduction Program (IP). The programs represents students with different past successes or challenges in their learning processes. The study included 70 students from SSP, 51 students from HSC, 75 from VHP, and 30 from IP. Table 1 shows the distribution between girls and boys.

\section{Table 1. Information on participating high school programs with regard to gender}

\begin{tabular}{lllllll}
\hline Program & & SSP & HSP & VHP & IP & Total \\
\hline Gender & Girls & $49(71 \%)$ & $\begin{array}{l}48 \\
(94 \%)\end{array}$ & $\begin{array}{l}21 \\
(28 \%)\end{array}$ & $1757 \%)$ & 136 \\
& Boy & $21(29 \%)$ & $3(6 \%)$ & $\begin{array}{l}53 \\
(72 \%)\end{array}$ & $13(43 \%)$ & 90 \\
& & & & $\mathbf{7 5}$ & $\mathbf{3 0}$ & $\mathbf{2 2 6}$ \\
\hline Total & & $\mathbf{7 0}$ & $\mathbf{5 1}$ & & & \\
\hline
\end{tabular}

\subsection{Data collection and data analysis}

The design of questions for the group interviews was influenced by a study by Blomgren (2016). A total of 12 students were selected by their teachers for interviews. The selection criteria were groups of students that included boys and girls that had varying study success. They are encoders designated with the letters E1-E12. We conducted and recorded the interviews onsite at the school and, subsequently, transcribed them. The interviews lasted between 40 min and $1.5 \mathrm{~h}$. When we converted the interviews into Word files (in 12-point, Times New Roman font), the transcribed interviews consisted of about 100 A4 pages of text.

The web survey was based on a modified questionnaire from Blomgren's study, and questions about learning strategies were based on the PEPS learning style test (Dunn, Dunn \& Price, 2000), but they have been reduced to only three response options: "yes," "no," and "don't know." Above all, in the interviews and the questionnaire, we focused on issues that previous research pointed to as being interesting to study in more detail or having aspects that were still unexplored. When we finished designing the final draft of the questionnaire, we sent information about the web survey to designated teachers to pass on to the relevant student groups. The 
survey was answered electronically as a web survey, using the Netigate survey accounting program, and it underwent statistical processing in SPSS. The survey is based on group selection and, therefore, no dropout of individuals was included in the survey. Only surveys with complete answers were processed and analyzed.

\subsection{Thematic analysis}

We analyzed interview data using inductive thematic content analysis, which is a method for systematic and gradual classification of data to identify patterns and themes more easily. Inductive coding is, by definition, not tied to theoretical framework (Braun \& Clarke, 2006), so the coding is driven by students' responses. Traditional content analysis can be divided into three stages: (1) selection of focus texts, (2) coding the text, and (3) interpretation of the results. Content analysis of open answers shows thematic differences (Hsieh \& Shannon, 2005). The chosen approach also enables analyses from different theoretical perspectives. The process followed common practice (Graneheim \& Lundman, 2004). Based on this, the analysis occurred in four steps: (1) we read through the text several times to get a sense of the content; (2) we divided the text into meaning units (i.e., a word, sentences, or a paragraph with the same content), guided by the aim of the study and condensed; and (3) we compared the condensed meaning units and sorted them into categories based on similarities and differences in content (see Table 2). We read the entire text (analysis unit) repeatedly to gain a holistic understanding of the text. Based on sentences or phrases, we condensed the content into categories that reflected the central message. These subcategories constituted the manifest content of the texts that were ultimately used to find categories (Krippendorf, 2019). Table 2 exemplifies this research process.

Table 2. Example of inductive analysis of data

\begin{tabular}{|c|c|c|c|c|}
\hline Meaning unit & Condensed unit & Subcategory & Category & Research Question \\
\hline $\begin{array}{l}\text {... Some may have } \\
\text { PowerPoint } \\
\text { presentations for } \\
\text { hours/../after an } \\
\text { hour you just think } \\
\text { "I don't know what } \\
\text { you said to my } \\
\text { brain ...it is dull } \\
\text { from that." And it } \\
\text { just becomes like a } \\
\text { dark room and you } \\
\text { just sit. }\end{array}$ & $\begin{array}{l}\text { Teaching affects } \\
\text { students' motivation }\end{array}$ & $\begin{array}{l}\text { Teaching } \\
\text { arrangement }\end{array}$ & $\begin{array}{l}\text { Teaching } \\
\text { strategies }\end{array}$ & $\begin{array}{l}\text { What determines } \\
\text { upper secondary } \\
\text { school students' } \\
\text { motivation/lack of } \\
\text { motivation to study } \\
\text { in each of the four } \\
\text { study programs? }\end{array}$ \\
\hline
\end{tabular}

Finally, as the researchers and authors of this article, we met and discussed the analysis thoroughly until we reached a consensus (Graneheim \& Lundman, 2004). This resulted in further refinement of themes, which ending up in a final thematization (Figure 2).

\subsection{Statistical method: cross-sectional study}

The survey is a statistical, cross-sectional study. A significance level of 0.05 was used. Multiple responses were analyzed with a chi-squared test with correction so that the $p$-value was calculated with Scott-Rao Chi squared test (Lavassani et al., 2008). Thus, it is possible to determine whether or not there are significant differences in the frequency distribution among the four vocational programs. The correction was made as follows: 


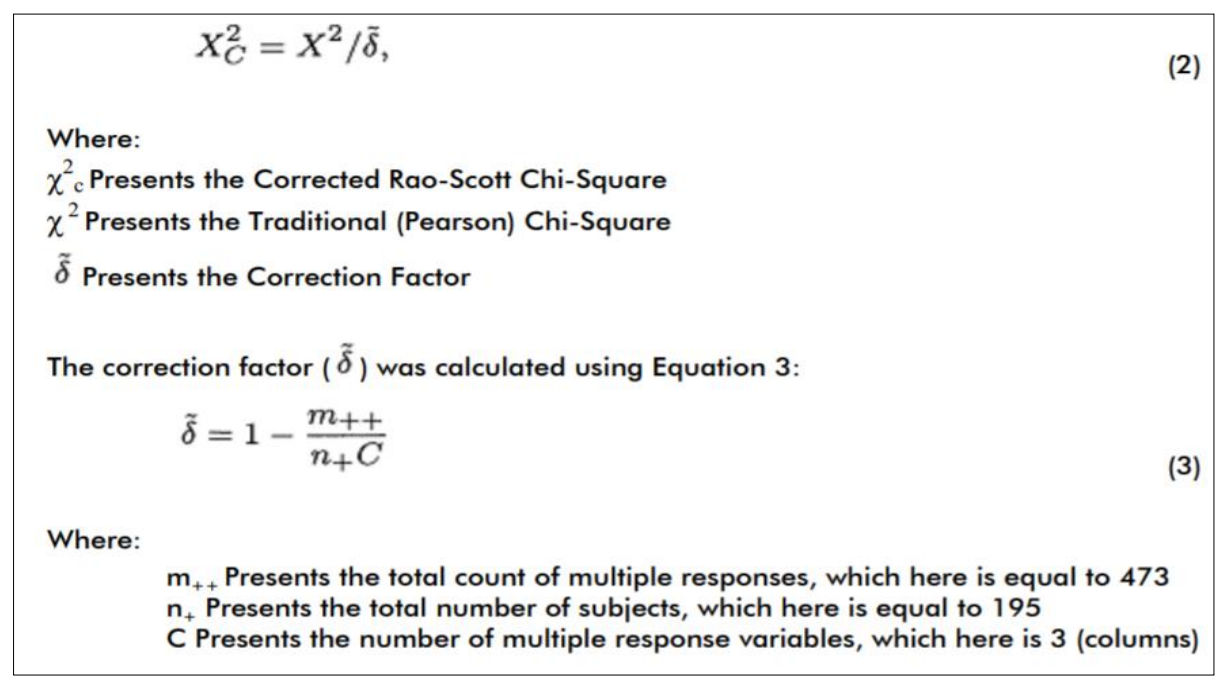

Figure 1. Correction of $x^{2}$ values (according to Lavassani et al., 2008).

\subsubsection{Selected variables}

The variables that we selected to determine if there were differences among the study programs were factors related to learning strategies, teaching strategies, and the teacher's role. It is possible to dichotomize the need for structure in learning into external structure and internal structure (i.e., of the student themselves). The former concerns the student's need for clear explanations and examples of how a task can be solved, as well as clearly communicated time and planning frameworks. The latter relates to the idea that learners learn best when they are allowed to think, structure, and plan for themselves. We selected five variables related to perceptual preferences (Dunn \& Griggs, 2007). Visual text means that a student learns best from written text. Visual image includes visualizations of content, such as images, illustrations, and graphs. Auditory learning means that a student learns best by listening and talking. Kinesthetic learning (learning-by-doing) means that a learner learns best by experiencing and physically participating in the learning. Tactical learning (hands-on learning) means that the learner learns best when their hands are active in learning processes. Social preferences include the kind of group constellation that best facilitates learning for a given student: alone, in a group, or with a teacher. Variation in teaching bears on whether a student prefers the teacher to change teaching methods or use the same method all the time. Goals and feedback were originally part of the concept of motivation, but, in this study, we have chosen to focus on whether the student needs short goals and quick feedback or would prefer to set their own goals. We selected the following variables to identify and analyze teaching strategies: methods defined in the study, including problem-based learning, learning via textbooks, and projectbased learning; class structure, including individual learning and learning in smaller groups; learning resources, including questions about textbooks, digital resources, and exercises in courses.

\subsection{Method discussion}

Like all similar studies, the results presented here should be viewed as snapshots. Learning strategies and desired teaching strategies can change over time (Dunn \& Griggs, 2007). To go deeper, repeated measurements and larger populations are required. The study is limited to four programs, and the results are valid for those included in the study. Given the number of students in each class, this is adequate for the chosen design (Hassmén \& Koivula, 1996). One 
strength of the study is that it is based on a multiple choice method, which strengthens the results. One weakness is that we could have extended the response options to each question. Then, possibly, we could have obtained more precise results.

\section{Results and analysis}

In Figure 2, we present an overview of the main categories and sub-categories found. We then present the results from the thematic analysis. After this, we show the distinctively statistically significant factor of importance between the four programs.

\subsection{Five thematic categories}

The thematic analysis resulted in five main themes: a) learning strategies, b) teaching strategies, c) teachers, d) learning environment, and e) others. For each theme, different subthemes were identified (see Figure 2). Each of these themes will be described and illustrated by quotations.

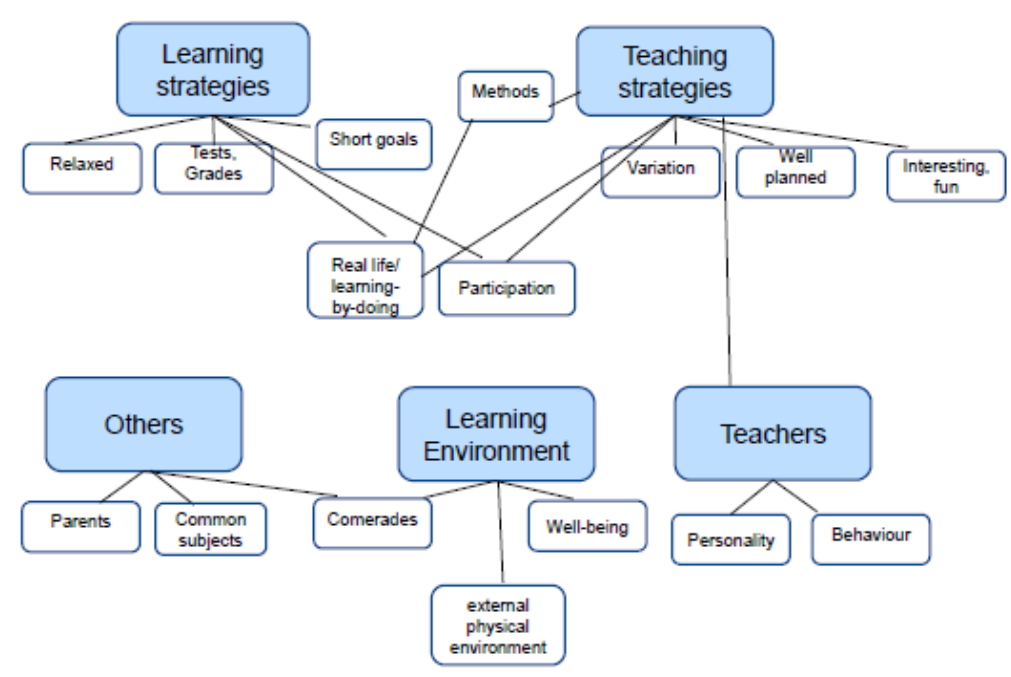

Figure 2. Thematic map. The blue ovals correspond to the five main categories, and the white ovals correspond to the sub-categories.

As shown in the thematic map, there are sub-categories that can be attributed to more than one main category. For example, the sub-category "comrades" was about the learning environment but can also be found in other contexts, such as leisure time outside the classroom.

Furthermore, the thematic map shows that the main categories interact with each other, for example teaching strategies are very much intertwined with the teacher.

Students' learning strategies for study motivation was a prominent theme in the empirical material. Five motivational study aspects for students were the importance of feeling relaxed, if they succeed on tests and with grades, short-term goals, participation in the studies, and more practical learning methods. Grades can both increase and decrease motivation. "If I get a high grade on one assignment, I get motivated for the other. Grading gives motivation (E2)." "If I get bad grades... or are behind, then I can't work at all. It will be a vicious circle (E4)." The overall picture was that grades could create study motivation, but that they could also be inhibitory to motivation if they were low. "The whip, it's to get the good grades then, because you should be 
able to apply to university or whatever ... (E10)." The informants also problematized the ratings as structurally inhibitory and stress-related factors.

The teaching strategies of teachers were of utmost importance for the study motivation of students. Students wanted a more practical and laboratory arrangement of lessons, such as learning-by-doing methods and content about "real life." The students emphasized the importance of choosing a method and having access to a variety of working methods. "When I get motivated, there is a variation in pedagogy, with varying tasks and subject areas (E6)." If the arrangement was not sufficiently well-planned or too monotonous, the study motivation of the students decreased. The study motivation of the students decreased or increased depending on the organization of the courses, such as if courses were planned well and if the courses included participation. Planning includes both the teacher's lesson and course planning, joint planning, and the students' own planning. The word "pleasure" embodies a strategy that leads to study motivation according to the consensus of the students. "Pleasure provides motivation (E7)."

The teacher was also significant in the students' study motivation, which is evident in this study. Most prominent was their personality and behavior. The study showed that the teacher's personal qualities were important for study motivation. For example, it was desirable for teachers to be happy, have understanding, have skills to provide support for the students, and not cause stress for the students. If teachers and students build good relationships, the study motivation is positively affected. Good relationships facilitate educational assignment, such as by providing feedback and setting the right requirements.

Concerning the learning environment, the general well-being, safety, and the class (fellow students) were described as important aspects in the learning environment. Well-being was involved being happy with both the teacher and the class, but this also applied in a physical sense, namely being happy on the premises. The impact of the external environment on the study motivation was even described as underestimated. Confidence was also emphasized in the interviews. "You feel safe and comfortable and you enjoy being here, easier then with homework and assignments (E1)." Students also emphasized the importance of the class or group in the learning environment as an influencing factor for their study motivation.

The category others contains information that is difficult to epitomize. For example, comrades are also associated with the "other" context of classroom interaction. "Correct peers" (ie comrades with positive attitudes to study) are crucial to study motivation in that they can positively affect study motivation, and, with the "wrong peers", the impact becomes negative. However, it seems difficult to break away from a peer group that does not want to work, as illustrated by the following student quote: "If I hang out with some friends, and they don't even want to work, I lose the motivation. It is difficult to change friends. It is up to me if I should follow them... I still have my own responsibility (E10)." Informants also described parental support as ambivalent. Some students had parents who supported them, and others did not have this support. A dilemma that the students described was that supportive parents could also lead to experiencing pressure to continue to perform well. This could be perceived as a negative or problematic expectation structure. Another sub category that is found here, but which is also related to the learning strategies of students, is common subjects (mathematics, Swedish, reading, writing and speaking in English), which were not as popular with the students in the vocational programs. These subjects lowered study motivation. 


\subsection{Differences in study motivation}

On the basis of the previous results, statistical analysis has been performed to investigate whether there are differences between the programs regarding learning and teaching strategies and the importance of the teacher (Table 3).

Table 3. Learning and teaching strategies as motivational preferences

\begin{tabular}{|c|c|c|c|c|c|c|c|c|c|c|c|c|c|c|}
\hline \multirow[b]{3}{*}{ Learning and teaching } & \multicolumn{12}{|c|}{ Program } & \multicolumn{2}{|c|}{ Statistics } \\
\hline & \multicolumn{3}{|c|}{ SSP } & \multicolumn{3}{|c|}{ IP } & \multicolumn{3}{|c|}{ VHP } & \multicolumn{3}{|c|}{ HSP } & \multirow[b]{2}{*}{$\mathrm{x} 2$ * Df } & \multirow[b]{2}{*}{$\mathrm{p}$} \\
\hline & $\mathrm{N}$ & $\mathrm{n}$ & $\%$ & $\mathrm{~N}$ & $\mathrm{n}$ & $\%$ & $\mathrm{~N}$ & $\mathrm{n}$ & $\%$ & $\mathrm{~N}$ & $\mathrm{n}$ & $\%$ & & \\
\hline Structure or construction & 48 & & & 19 & & & 4 & & & 40 & & & 12.03 & 0.007 \\
\hline Clear structure & & 4 & $90 \%$ & & 18 & $95 \%$ & & & $80 \%$ & & 38 & 95 & & \\
\hline Independent thinking & & 1 & $40 \%$ & & 11 & $58 \%$ & & 31 & $69 \%$ & & 22 & 55 & & \\
\hline Perceptual preferences & 55 & & & 22 & & & 5 & & & 44 & & & 24.012 & 0.020 \\
\hline Reading text & & 2 & $51 \%$ & & 11 & $50 \%$ & & & $53 \%$ & & & 57 & & \\
\hline Looking at images & & 3 & $67 \%$ & & 10 & $46 \%$ & & & $72 \%$ & & & 73 & & \\
\hline Listening (to teacher or peer) & & 4 & $82 \%$ & & 13 & $59 \%$ & & & $74 \%$ & & & 75 & & \\
\hline Learning-by-doing & & 4 & $76 \%$ & & 16 & $73 \%$ & & & $96 \%$ & & & 91 & & \\
\hline Tactual learning & & 2 & $47 \%$ & & 12 & $55 \%$ & & & $85 \%$ & & & 89 & & \\
\hline Socological preferences & 55 & & & 26 & & & 5 & & & 45 & & & 6.556 & 0.365 \\
\hline Best alone & & 2 & $49 \%$ & & 15 & $58 \%$ & & 25 & $48 \%$ & & & 71 & & \\
\hline Best in group & & 3 & $60 \%$ & & 11 & $42 \%$ & & 29 & $56 \%$ & & & 64 & & \\
\hline Best with teacher & & 4 & $78 \%$ & & 18 & $69 \%$ & & 42 & $81 \%$ & & & 82 & & \\
\hline Variation in teaching & 48 & & & 15 & & & 4 & & & 42 & & & 13.63 & 0.003 \\
\hline Different ways of teaching & & 4 & $90 \%$ & & 14 & $93 \%$ & & 30 & $73 \%$ & & & 88 & & \\
\hline Similar ways of teaching & & 1 & $25 \%$ & & 4 & $27 \%$ & & 21 & $51 \%$ & & & 41 & & \\
\hline Motivation & 43 & & & 20 & & & 4 & & & 40 & & & 4.833 & 0.184 \\
\hline Given short goals and quick & & 3 & $88 \%$ & & 19 & $95 \%$ & & 34 & $85 \%$ & & 34 & 85 & & \\
\hline Setting own learning goals & & 2 & $53 \%$ & & 10 & $50 \%$ & & 25 & $63 \%$ & & 28 & 70 & & \\
\hline
\end{tabular}

${ }^{*}$ Rao-Scott Chi square, which is adapted for situations with multiple response variables.

In all four programs, $80 \%$ to $90 \%$ of the students preferred a clear structure. Many also preferred independent thinking, that number being $40 \%$ to $69 \%$ of the answers. The difference between the programs was that the social sciences program had a relatively lower proportion compared to the other programs that preferred independent thinking $(40 \%)$. The vehicle and transport program had a higher proportion of preferring independent thinking but had a lower proportion than others in preferring clear structure. The differences are significant (Rao-Scott $x 2$ $=12.05 ; \mathrm{df}=3 ; \mathrm{p}=0.007$ ).

Concerning perceptual preferences, it was a percentage spread. For example, students in the practical programs appeared to have a higher preference for learning-by-doing and tactual learning. The differences were significant. Regarding sociological preferences, there were no statistically significant differences, but it is noteworthy that many students in all four classes experienced a great need for interaction with the teacher $(78 \%-82 \%)$. There is also a significant difference between the four programs regarding variation in teaching. There is no statistical difference between the programs in relation to the preference of the students for short-term goals and feedback $(88 \%-95 \%$ of the students).

As teaching methods are a decisive and interconnected hub between the categories and in didactic theory, we also tested this for significant differences between the study programs. We 
calculated significance for three aspects of teaching methods in a similar way; we used didactical methods, constellation for learning, and learning media. Table 4 shows that in all three of the selected teaching methods, there were statistically significant differences between the study programs.

Table 4. Teaching methods as motivational strategies

\begin{tabular}{|c|c|c|c|c|c|c|c|c|c|c|c|c|}
\hline \multirow[b]{3}{*}{ Teaching methods } & \multicolumn{10}{|c|}{ Program } & \multicolumn{2}{|c|}{ Statistics } \\
\hline & \multicolumn{3}{|c|}{ SSP } & \multicolumn{2}{|r|}{ IP } & \multicolumn{2}{|c|}{ VHP } & \multicolumn{3}{|c|}{ HSP } & & \\
\hline & $\mathrm{N}$ & $\mathrm{n}$ & $\%$ & $\mathrm{~N}$ & $\mathrm{n} \quad \%$ & $\mathrm{Nn}$ & $\%$ & $\mathrm{~N}$ & $\mathrm{n}$ & $\%$ & $x^{2 *} \mathrm{Df}$ & $p$ \\
\hline Didactic methods & 25 & & & 16 & & 31 & & 21 & & & 42.66 & 0.000 \\
\hline Examples, much problem- & & 16 & $64 \%$ & & $425 \%$ & & $929 \%$ & & 7 & 33 & & 36 \\
\hline Much textbook learning & & 6 & $24 \%$ & & $1488 \%$ & & $2581 \%$ & & 14 & 67 & & 36 \\
\hline Much project-oriented learning & & 10 & $40 \%$ & & $0 \quad 0 \%$ & & $5 \quad 16 \%$ & & 9 & 43 & & 31 \\
\hline Constellation for learning & 57 & & & 25 & & 48 & & 43 & & & 13.93 & 0.003 \\
\hline Much individual learning & & 51 & $90 \%$ & & $2080 \%$ & & $3573 \%$ & & 34 & 79 & & \\
\hline Much small group learning & & 28 & $49 \%$ & & $624 \%$ & & $3063 \%$ & & 24 & 56 & & \\
\hline Learning Media & 37 & & & 21 & & 37 & & 25 & & & 23.76 & 0.001 \\
\hline Good textbook in our courses & & 20 & $54 \%$ & & $1571 \%$ & & $2978 \%$ & & 21 & 84 & & \\
\hline Digital learning media in our & & 32 & $87 \%$ & & $733 \%$ & & $2978 \%$ & & 12 & 48 & & \\
\hline Good exercises in our courses & & 14 & $38 \%$ & & $1048 \%$ & & $1849 \%$ & & 8 & 32 & & \\
\hline
\end{tabular}

${ }^{*}$ Rao-Scott Chi square, which is adapted for situations with multiple response variables.

In conclusion, the results from the survey show that there are significant differences between the programs in several different respects, i.e., structure, perceptual preferences, variation, and different teaching methods.

\section{Discussion}

In this part of the article we present our conclusions of the results of the study and their didactical implications, followed by a methods discussion and suggestions for further research.

\subsection{Conclusions}

In this study, five different and partially interacting areas could be defined as significant to understand what determines the motivation or lack of motivation to study for upper secondary school students, i.e., learning and teaching strategies, teachers, learning environment, and others.

The learning strategies that the students emphasized in this study were the abilities to be relaxed and not feel stressed, cope with assignments and tests, which they could do with shortterm goals, gain learning methods of a more exploratory nature, and to be able to participate in the planning of the work. Blomgren (2016) states that "students' ability is enhanced by support aimed at getting students to use effective learning strategies and effort" (p. 243). However, which effective teaching strategies were included was not clarified by Blomgren. The present study indicates a number of learning strategies at the collective level but not at the individual level. What is made clear is the need for a practically-oriented pedagogy with tangible benefits from the knowledge. The importance of methods that facilitate learning was made clear by the students in this study. If didactic planning of the teachers and the teaching methods can match the learning strategies of the students, this can have a positive effect on student results and study motivation (Dunn \& Griggs, 2007). We found structure to be significant. It is evident that all programs express a great need for external structure. This is in line with previous research 
(Boström, 2013; Boström \& Gidlund, 2016). The abilities and insights of students to take responsibility for their own learning was not something that the students in this study pointed out, although previous research showed it to be crucial for success in studies. We can only speculate upon the reasons for this. Is it a new generation of young people who only see external motivation as promotion? Or are theories of intrinsic motivation for students overestimated?

An important link between teaching strategies is methods. The study shows statistical differences between the four programs that we can speculate on. Are there more digital teaching resources in some programs, or do students learn better in some of the programs through some special learning method? This is somewhat supported in an earlier study (Boström \& Bostedt, 2019).

The teaching strategies of teachers are closely linked to study motivation in students. In this study, students expressed that planning, variation, methods, real life learning, interesting lessons, and participation are crucial to their study motivation. Previous studies have shown the importance of teachers' attitudes, choice of didactic work methods, leadership, didactic action skills, and planning (cf., Håkansson \& Sundberg, 2015). They also showed the reciprocal relationship between learning and teaching (Aspelin, 2019; Perry et al., 2006).

This study confirms previous research (cf., 2013; Hattie, 2009) of the teacher as an important player in students' studies. This is evident in the descriptive statistics and interviews. The teacher's personality and behaviors are viewed by the students as the most important capacity. According to the students, a motivated teacher is someone who is friendly, fun, understanding, and has a fair attitude. The teacher's competence was not emphasized to any great extent by the students, which differs from Blomgren's (2016) conclusion.

This study points out that well-being and security in the learning environment are important and that the class/group/comrades provide a motivational context for the students. The students believe that the external learning environment, such as premises and benches, also played an important role in study motivation. Good learning environments are important in school, as well as in other workplaces or learning situations. To best support students, knowledge is needed on how good learning environments can be established as people interact, influence, and are influenced by the social and physical environment (Ahlberg, 2001).

The hard to define category of others is tangible to the learning environment, as students think that friends are important for motivating or demotivating studies. In this context, it is more about the different groups of peers they hang out with and how the group pressure acts as study motivation. The same goes for parents, who can be both motivating or demotivating for study. This aspect occurs only to a small extent in previous research, which is why it is important to highlight in this article.

Reasons for having a lack of study motivation can preferably be sought in factors like learning environments (Ahlberg, 2001), learning strategies (Boström, 2011a, 2011b), teaching planning (Blomgren, 2016), individual aspirations (Woolfolk \& Karlberg, 2015), didactical choices (Håkansson \& Sundberg, 2015), the physical environment (Lundahl et. al, 2015), and inner/external motivational factors (Wery \& Thomson, 2013). 
The research question of if there are differences between the four programs concerning study motivation can be answered in the affirmative. This study shows some statistically significant differences concerning teaching and learning strategies and teaching methods.

In summary, we believe that teaching and teaching strategies can be seen as a processes integrated into a larger whole that are impossible to separate from individual differences, the nature of tasks, or the characteristics of teachers (cf., Hugo, 2006).

\subsection{Didactical implications}

Teaching in different programs requires a broader didactic repertoire, as the more theoretical subjects differ, to some extent, from the more practical ones (Herrera et al., 2018). Thus, teachers need to have good knowledge of student and group learning. This study shows that the four programs exhibit similar study strategies at the group level but also some significant differences. Changing teaching methods and taking into account what students experience in student motivation, such as variation, high structure, and more practically-oriented teaching methods, is an important and necessary didactic challenge for teachers. Pupils and teachers have different perceptions of student motivation (Boström \& Bostedt, 2019). Therefore, knowledge of student learning strategies at the individual, group, and program level is crucial. Secondly, taking into account student voices is important to allow support for students in their study motivation. The fact that both teachers when considered as a group and individual teachers reflect the didactic choices of teacher and methods in different programs is a didactical implication of this study. In summary, we also believe that the results of this study are a constructive contribution to the importance of developmental work in the classroom, where the greatest opportunity exists to influence the results and study motivation of students (cf., Hattie, 2009).

\subsection{Continued research}

In future research, we will increase the number of students and teachers who answer the questionnaire. Furthermore, we will select more cases so that we can present and analyze the results based on a multiple-case study. We will make the selection of cases with an ambition to maximize the variation in terms of, for example, geographical distribution, size of municipality, and types of organizer (independent school or municipal school). Furthermore, we will compare the results from vocational programs to theoretical programs. Consequently, conducting studies at group and program levels to better understand students in different programs is a basis for developing didactics and finding different and more precise paths to encouraging study motivation in students. 


\section{References}

Ahlberg, A. (2001). Lärande och delaktighet [Learning and participation].Lund: Studentlitteratur.

Aspelin, J. (2018). Lärares relationskompetens [Teacher's relationship skills].Stockholm: Liber.

Augustsson, G., \& Boström, L. (2016). Teachers' leadership in the didactic room: A systematic literature review of international research. Acta Didactica Norge - tidsskrift for fagdidaktisk forsknings- og utviklingsarbeid i Norge, (10), 1-19. https://doi.org/10.5617/adno.2883

Blomgren, J. (2016). Den svårfångade motivationen: elever i en digital lärmiljö [The hard-won motivation: students in a digital learning environment]. [Diss), Göteborg: Göteborgs Universitet.

Boström, L. (2011a). Elevers lärstilar i jämförelse med deras lärares lärstilar. En jämförande studie av elever och lärare i ungdomsskolan i Danmark. [Students 'learning styles in comparison with their teachers' learning styles. A comparative study of pupils and teachers in secondary school in Denmark]. Pædagogisk Psykologisk Tidsskrift, (48)6, 560-580.

Boström, L. (2011b). A comparative study of two different student teacher groups in Sweden. The Quality of Higher Education,(8), 158-178.

Boström, L (2013). Hur lär sig elever på sex olika yrkesprogram? En studie om skillnader och likheter i lärstilar [How do students learn about six different vocational programs? A study on differences and similarities in learning styles]. Utbildning \& Lärande, (4)1, 48-65.

Boström, L., \& Bostedt, G. (2019). Studiemotivation i gymnasieskolan? Elevers och lärares perspektiv på dess möjligheter och utmaningar [Student motivation in upper secondary school? Students 'and teachers' perspectives on their opportunities and challenges].[Unpublished manuscript].

Boström, L. \& Gidlund, U. (2016). Students' need for structure-the forgotten learning styles preference. Assessment, Performance and Effectiveness New York: Nova Science Publishers, York : Nova Science Publishers, 12-20.

Braun, V., \& Clarke, V. (2006). Using thematic analysis in psychology. Qualitative Research

in Psychology, (3)2, 77-101. https://doi.org/10.1191/1478088706qp063oa

Dunn, R., Dunn, K., \& Price, G. E. (2000). Productivity environmental preference survey.

Price System.

Dunn, R., \& Griggs, S. (2007). Synthesis of the Dunn and Dunn learning style model: Who, what, when, where, and so what? Center for the Study of Learning and Teaching Styles.

Farrington, C., Roderick, E., Allensworth, E., Nagaoka, J., Keyes, T., Johnson, D., \& Beechum, N. (2012). Teaching adolescents to become learners. The role of noncognitive factors in shaping school performance: A critical review. University of Chicago Consortium and Chicago School Research.

Giota, J. (2013). Individualisering i skolan - vilken, varför och hur? [Individualization at school - which, why and how?]. Vetenskapsrådets rapportserie,(3). Stockholm.

Giota, J. (2017, Oct. 30). Den svårfångade motivationen, elevers välmående och skolprestationer. Lecture. [The hard-captured motivation, student well-being and school achievement]. Sundsvalls kommun.

Graneheim, U. H., \& Lundman, B. (2004). Qualitative content analysis in nursing research: Concepts, procedures and measures to achieve trustworthiness. Nurse Education Today, 24(2), 105-112. https://doi.org/10.1016/j.nedt.2003.10.001

Granström, K. (2012). Tre aspekter på lärares ledarskap i klassrummet, i Berg, G., Sundh, F., Wede, C (Red). (2012). Lärare som ledare (s. 27-48). Lund: Studentlitteratur

Hattie, J. A. C. (2009). Visible learning: A synthesis of over 800 meta-analyses relating to achievement. Routledge. https://doi.org/10.4324/9780203887332

Hassmén, P., \& Koivula, N. (1996). Variansanalys. Studentlitteratur.

Herrera, L. M., Teräs, M., \& Gougoulakis, P. (2018). Emergent issues in research on vocational education \& training (Vol. 1). Premissförlag. https://doi.org/10.1007/978-3-319-49789-1_61-1

Hsieh, H., \& Shannon, S. (2005). Three approaches to qualitative content analysis. Qualitative Health Research, 15(9) 1,277-1,288. https://doi.org/10.1177/1049732305276687

Hugo, M. (2006). Liv och lärande i gymnasieskolan: En studie om elevers och lärares erfarenheter i en liten grupp på gymnasieskolans individuella program [Life and learning in upper secondary school: A study of lifts and teachers' experiences in a small group on the upper secondary school's individual programs]. (Diss). Jönköping:Jönköping University.

Håkansson, J. \& Sundberg, D. (2012) Utmärkt undervisning. Framgångsfaktorer i svensk och internationell belysning [Excellent teaching. Success factors in Swedish and international lighting]. Stockholm: Natur och Kultur.

Jerkeby, S. (2019). Att redan vara motiverad - om hinder och möjligheter för lärande [To be motivated already - about barriers and opportunities for learning]. Lund: Studentlitteratur.

Karlberg, M. (2011) Skol-Komet: tre utvärderingar av ett program för 
beteendeorienterat ledarskap $i$ klassrummet [Skol-Komet: three evaluations of a program for behavioral leadership in the classroom.]. (Diss), Uppsala: Uppsala university.

Krippendorf, K. (2019). Content analysis: An introduction to its methodology. Sage.

Lavassani, K. M., Movahedi, B., \& Kumar, V. (2008). Developments in analysis of multiple response survey data in categorical data analysis: The case of enterprise system implementation in large North America firms. Journal of Applied Quantitative Methods, (4)1, 45-53.

Lundahl, L., Lidström, L., Lindblad, M., Lovén, A., Olofsson, J. \& Öst, J. (2015). Osäkra övergångar [Unsafe transitions]. I: Resultatdialog 2015 (s. 107-116). Stockholm: Vetenskapsrådet.

Perry, N. E., Turner, J. C., \& Meyer, D. K. (2006). Classrooms as context for motivating learning. In P. A. Alexander \& P. H. Winne (Eds.), Handbook of educational psychology (pp. 1-64). Erlbaum.

Ryan, R. M., \& Deci, E. L. (2002). An overview of self-determination theory. In E. L. Deci \& R. M. Ryan (Eds.), Handbook of self-determination research (pp. 3-33). University of Rochester Press.

Skolverket. (2016). Uppföljning av gymnasieskolan [Follow-up of upper secondary school]. Skolverket: Stockholm.

Skolverket. (2018). Betyg och studieresultat i gymnasieskolan år 2018 [Grades and study results in upper secondary school in 2018]. PM. Dnr 2018:1905. Stockholm: Skolverket.

Skolverket. (2019). Uppföljning av gymnasieskolan 2019 [Follow-up of upper secondary school 2019]. Rapport 480. 2019. Stockholm: Skolverket.

Skolverket (2020a). Uppföljning av gymnasieskolan 2019 [Follow-up of upper secondary school 2019]. Rapport 2020:4. 2020 Stockholm: Skolverket.

Skolverket (2020b) https://siris.skolverket.se/

Sjöberg, L. (1997). Studieintresse och studiemotivation: en analys av de grundläggande faktorerna [Student interest and study motivation: an analysis of the basic factors]. Stockholm: Institutet för individanpassad skola.

Sveriges Elevkårer (2018). Aftonbladet. Debattartikel torsdagen 31 maj 2018.

Sveriges Elevkårer \& Lärarnas Riksförbund (2015). Från avhopp till examen - en undersökning bland gymnasieelever och lärare om faktorer som påverkar genomströmningen i gymnasieskolan [From drop-out to graduation - a survey among high school students and teachers about factors that affect the throughput in high school]. Stockholm.

Wery, J., \& Thomson, M. (2013). Motivational strategies to enhance effective learning in teaching struggling students. British Journal of Learning Support, (38)103-108. https://doi.org/10.1111/14679604.12027

Vetenskapsrådet. (2017). God forskningssed [Good research practice]. Vetenskapsrådet.

Vinterek, M. (2006). Individualisering i ett skolsammanhang [Individualization in a school context]. Myndigheten för skolutveckling. Stockholm: Skolverket.

Woolfolk, A., \& Karlberg, M. (2015). Pedagogisk psykologi [Educational psychology]. Pearson Education Limited.

Zimmerman, F. (2018). Det tillåtande och det begränsande. En studie om pojkars syn på studier och ungdomars normer kring maskulinitet [The permissive and the restrictive. A study on boys 'views on studies and adolescents' norms about masculinity] (Diss). Göteborg: Göteborgs universitet.

Funding: This work was supported by Mid Sweden University and the Municipality of Sundsvall [Dnr MIUN 2017/1880].

Conflict of interest: We have no conflicts of interest to declare. 